References
1. Tsyvilnyi kodeks Ukrainy vid 16 sichnia 2003 r. (z nastupnymy
zminamy ta dopovnenniamy stanom na 31.10 .2018$)$. URL:
http://zakon1.rada.gov.ua/laws/show/435-15 (in Ukrainian).
2. Puchkovs'kal. J. Teoretychni problemy zabezpechennja zobov'jazan':
monografija [Theoretical problems of securing obligations]. Harkiv: Pravo,
2017. 472 s. (in Ukrainian).
3. Nad'on V. V. Sub'jektyvnyj obov'jazok jak element zmistu cyvil'nyh
pravovidnosyn [Subjective obligation as an element of content in civil legal
relationships]: monografija. Harkiv : Pravo, $2017.392 \mathrm{~s}$. (inUkrainian).

4. Lejst E. Je. Sankcii v sovetskomprave [Sanctions in Soviet law]. M., 1962. 238 s. (in Russian).

5. Alekseev S.S. Obshhaja teorija prava [General Theory of Law]: $\vee 2$ tomah. T. 1. M.: Jurid. lit., 1981. 361 s. (in Russian).

Received: $10 / 02 / 2020$

1st Revision: $04 / 03 / 2020$

Accepted: $01 / 04 / 2020$

I. Dzera, PhD (Law), Associate Prof.

National University of Kyiv-Mohyla Academy, Kyiv, Ukraine

\title{
THE SYSTEM OF CIVIL SANCTIONS IN THE GENERAL PART OF THE CIVIL CODE OF UKRAINE
}

In this article the norms of Books 1-3 of the Civil Code of Ukraine are examined in order to determine civil sanctions and their system. The author stipulates that in the Civil Code of Ukraine there is no definition for the specific term "sanction" and its types, except for Article 354, which states only one type of the sanction, that is, confiscation. These gaps lead to the problems in determining the grounds for the application of certain measures of coercive nature and impede the effective protection of subjective civil law rights which are violated.

A critical analysis of existing classifications of civil sanctions is carried out, and an author's classification of the General Part of the Civil Code's sanctions is proposed, depending on the types of legal relationships governed by it. For the purposes of such classification, the author considers the subjective composition of the legal relationship, the focus on the restoration of the subjective civil law right, which is violated, or on the compensation of the harm caused, and the consequences of civil sanctions application.

A thorough analysis of the norms of Books 1-4 of the Civil Code is carried out in order to identify the norms containing civil sanctions. Thus, in the first three chapters of the Civil Code there is a lack of the norms containing civil sanctions. At the same time, Chapter 4 of the Civil Code is distinguished by the variety of civil sanctions that are proposed to be considered as civil sanctions that limit or impede the personal civil status of an individual in the circumstances specified in Articles 36, 37, 39, 41, 43, 46, 47, 481. Other provisions of the same chapter contain sanctions that restore the civil status of an individual, which causes him or her to have positive legal effects (Articles 38,42$)$ related to the restoration of the civil capacity of an individual whose civil capacity has been is limited or recognized as incompetent.

On the basis of the conducted research of the norms of the Civil Code, it is concluded that the diversity of civil legal sanctions in different chapters of the Civil Code, which have different directions and consequences of their application, despite the absence of their direct name "sanctions".

Keywords: a sanction, protection of civil rights, civil liability, measures of liability.

Bulletin of Taras Shevchenko National University of Kyiv. Legal Studies, 2020; 1 (112): 23-26

УдК: 347.921 .65

DOI: https:doi.org/10.17721/1728-2195/2020/1.112-4
ISSN 1728-2195

(C) Taras Shevchenko National University of Kyiv,

Publishing center "Kyiv University", 2020

Т. Коротенко, здобувач Київський університет права НАН України, Київ, Україна

\section{СУДОВІ ВИТРАТИ, ПОВ'ЯЗАНІ 3 ВИКОНАННЯМ СУДОВИХ ДОРУЧЕНЬ, ЗВЕРНЕНИХ ДО КОМПЕТЕНТНИХ ОРГАНІВ ІНОЗЕМНИХ ДЕРЖАВ}

Досліджено питання судових витрат, що пов'язані з виконанням судових доручень, які звернені до компетентних органів іноземних держав у цивільних справах з іноземним елементом. У ЦПК України не зазначено, що витрати, пов'язані з виконанням судових доручень, звернених до компетентних органів іноземних держав, є судовими витратами. У зв'язку із цим виникає питання щодо того, які саме із зазначених вище витрат можна віднести до судових, а також який порядок їхнього відшкодування. Важливість з'ясування цього питання полягає у застосуванні єдиних підходів до врегулювання таких справ у судах, що і є метою нашої статті. У висновках ми пропонуємо судові витрати, пов'язані із виконанням судових доручень, звернених до компетентних органів іноземних держав, поділити на види залежно від процесуальних дій, які здійснюються, а також віднести витрати, пов'язані з виконанням судових доручень, звернених до компетентних органів іноземних держав, до витрат, пов'язаних із розелядом справи, а саме до витрат, що пов'язані з учиненням інших процесуальних дій, необхідних для розеляду справи або підготовки до їі розгляду. Це забезпечить право зацікавленої сторони у майбутньому на відшкодування таких витрат.

Ключові слова: судові витрати, витрати, пов'язані з розглядом справи, справи з іноземним елементом, цивільне судочинство.

Вступ. Конвенція про захист прав людини й основоположних свобод [2], Рекомендація щодо заходів, які полегшують доступ до правосуддя № R (81)7, прийнята Комітетом міністрів Ради Європи 14 травня 1981 р. [3] та практика Європейського суду з прав людини під час застосування цієї Конвенції не визнають необхідність сплати судових витрат обмеженням права доступу до суду. Водночас, ураховуючи положення п. 1 ст. 6 Конвенції та прецедентну практику Європейського суду 3 прав людини (зокрема, рішення від 19 червня 2001 р. у справі "Креуз проти Польщі" (Kreuz v. Poland)) [4], сплата судових витрат не повинна перешкоджати доступу до суду, ускладнювати цей доступ таким чином і такою мірою, щоб завдати шкоди самій суті цього права, та має переслідувати законну мету.
Судові витрати - це передбачені законом витрати (грошові кошти) сторін, інших осіб, які беруть участь у справі, понесені ними у зв'язку з її розглядом та врегулюванням, а у випадках їхнього звільнення від сплати це витрати держави, які вона несе у зв'язку з розв'язанням конкретної справи. Відповідно до положень ст. 133 ЦПК України судові витрати складаються із судового збору та витрат, пов'язаних із розглядом справи.

До витрат, пов'язаних із розглядом справи, належать витрати:

1) на професійну правничу допомогу;

2) пов'язані із залученням свідків, фахівців, перекладачів, експертів і проведенням експертизи;

3) пов'язані з витребуванням доказів, проведенням огляду доказів за їхнім місцезнаходженням, забезпеченням доказів; 
4) пов'язані із вчиненням інших процесуальних дій, необхідних для розгляду справи або підготовки до її розгляду.

Процесуальний закон прямо не вказує, що витрати, пов'язані з виконанням судових доручень, звернених до компетентних органів іноземних держав, $€$ судовими витратами.

На нашу думку, спірним питанням виявилося те, які ж витрати, пов'язані зі зверненням із судовим дорученням до компетентних органів іноземних держав, можна віднести до судових витрат та який порядок їхнього відшкодування.

Необхідність з'ясування цього питання полягає в тому, що від виду судових витрат залежить і порядок їхнього відшкодування, а це $є$ важливим як для кожного з учасників судового процесу, так і для визначення доступності правосуддя в конкретній справі.

Виклад основного матеріалу. Судова практика свідчить про те, що у більшості випадків, коли у суду виникає необхідність у зверненні із судовим дорученням до компетентних органів іноземних держав, зацікавлена особа має сплачувати за засвідчений переклад позовної заяви та доданих документів офіційною мовою запитуваної держави, а також сплачувати за проведення дій із вручення документів.

Витрати, пов'язані із засвідченням перекладу позовної заяви та доданих документів офіційною мовою запитуваної держави. Так, ухвалою Нікопольського міськрайонного суду Дніпропетровської обл. № 182/7393/19 від 28.10.2019 позовну заяву про визнання батьківства залишено без руху, суд вважає за необхідне надати позивачу термін для усунення зазначених недоліків і надання належним чином завіреного перекладу позовної заяви та долучених до позовної заяви документів англійською мовою [5].

Ухвалою Токмацького районного суду Запорізької обл. № 328/131/19 від 18.01.2019 позовну заяву про розірвання шлюбу залишено без руху. Відповідно до ухвали позивачу необхідно надати суду повний пакет документів із завіреним перекладом російською мовою (у двох примірниках) для подальшого можливого звернення із судовим дорученням до іноземного суду. Одночасно має бути поданий документ, який засвідчуватиме, що в особи, яка здійснила переклад, є такий дозвіл (сертифікат або інший дозвільний документ) [6].

Ухвалою Приморського районного суду м. Одеси № 522/18132/19 від 08.07.2019 у справі про відшкодування моральної шкоди постановлено: доручити компетентному органу Федеративної Республіки Німеччини вручити компанії-відповідачу такі документи: копію позовної заяви разом із додатками до неї та судові повістки про виклик на судове засідання на розгляд цивільної справи за позовом про відшкодування моральної шкоди; зобов'язати позивача (його представника) надати суду в термін до 23 липня 2019 р. переклад цієї ухвали суду англійською мовою у двох екземплярах [7].

Ухвалою Індустріального районного суду м. Дніпропетровська № 202/4354/19 від 01.07.2019 позовну заяву про розірвання шлюбу залишено без руху. У мотивувальній частині ухвали йдеться, що позивачу необхідно надати суду повний пакет документів із завіреним перекладом російською мовою (у двох примірниках), для подальшого можливого звернення із судовим дорученням до іноземного суду. Одночасно має бути поданий документ, який засвідчуватиме, що в особи, яка здійс- нила переклад, є такий дозвіл (сертифікат або інший дозвільний документ) [9].

Ухвалою Дніпропетровського районного суду Дніпропетровської обл. № 175/3613/17 від 29.01.2019 у справі про витребування майна із чужого незаконного володіння та скасування рішень про державну реєстрацію прав та їхніх обтяжень постановлено: доручити відповідному компетентному суду у Республіці Кіпр або іншому компетентному органу в Республіці Кіпр вручити відповідачу, місцезнаходження якого зареєстровано за адресою: Ніколау І. Ніколаілі, 10 будівля "Пітакіо", 2-й поверх, офр. 202 Пафрос. Кіпр. (Nikolaou I. Nikolaidi Ave, Paphos, Cyprus, 8010), ухвалу про прийняття до розгляду від 29 листопада 2018 р. та судову повісткуповідомлення про виклик на судове засідання; зобов'язати представника позивача надати до суду, протягом п'яти днів від дня отримання копії ухвали суду: нотаріально засвідчений переклад ухвали про прийняття до розгляду від 29 листопада 2018 р. грецькою мовою; судової повістки про виклик грецькою мовою [8].

Отже, суд, вирішуючи питання про відкриття провадження у справі та про звернення із судовим дорученням до компетентних органів іноземних держав, покладає обов'язок перекладу та його посвідчення на зацікавлену сторону.

Чи можна відносити зазначені витрати до виду судових витрат, що пов'язані із залученням перекладача, чи все ж таки це $є$ витратами, пов'язанами з учиненням інших процесуальних дій, необхідних для розгляду справи або підготовки до ії розгляду?

Ураховуючи те, що від надання зацікавленою стороною належним чином засвідченого перекладу залежить питання відкриття провадження та в подальшому саме звернення із судовим дорученням, то витрати пов'язані з його оплатою необхідо віднести до витрат, пов'язаних з учиненням інших процесуальних дій, необхідних для розгляду справи або підготовки до її розгляду.

Витрати, пов'язані зі здійсненням дій із вручення документів. Так, ухвалою Новоайдарського районного суду Луганської обл. № 419/2850/17 від 26.03.2018 постановлено позовну заяву про визнання права власності на спадкове майно залишити без руху. У мотивувальній частині ухвали йдеться: відповідач, фактично, мешкає в США. У випадках, коли існує потреба в передачі судових і позасудових документів для вручення за кордоном, застосовується Конвенція про вручення за кордоном судових і позасудових документів у цивільних або комерційних справах від 15.11.1965. За даними офріційного сайту Process Forwarding International of Seattle між Департаментом юстиції США та Компанією 30 січня 2015 р. набув чинності новий контракт, яким продовжено на п'ять років термін виконання Компанією повноважень щодо вручення судових документів. Нині вартість вручення становить 95 дол США. Оплату за здійснення дій із вручення документів позивачу необхідно сплатити на рахунок компанії "Міжнародне вручення процесуальних документів". Отже, позивачем не долучено до матеріалів позовної заяви документів, що підтверджують сплату вартості вручення документів у Сполучених Штатах Америки. Для забезпечення виконання судового доручення про вручення відповідачу копії позову та повідомлення про судовий розгляд позивачу необхідно сплатити кошти за виконання судового доручення в розмірі та на рахунок, що зазначені на вебсайті Гаазької конференції з міжнародного приватного права [10] 
Ухвалою Нікопольського міськрайонного суду Дніпропетровської обл. № 182/5601/19 від 03.09.2019 позовну заяву про розірвання шлюбу залишено без руху, зобов'язано позивача сплатити кошти за виконання судового доручення у розмірі, способом та на рахунок, що зазначені на вебсайтах Гаазької конференції з міжнародного приватного права: http://www.hcch.net, або компанії ABC Legal, яка здійснює діяльність як Process Forwarding International [11].

Суди України, звертаючись із відповідним запитом, оформленим на підставі Гаазької конференції про вручення за кордоном судових і позасудових документів у цивільних або комерційних справах від 15.11.1965 (далі Конвенція 1965 р.) відповідно до п. 6.7 Інструкції про порядок виконання міжнародних договорів з питань надання правової допомоги в цивільних справах щодо вручення документів, отримання доказів та визнання і виконання судових рішень, затвердженої спільним наказом МЮУ та Державної судової адміністрації України від 27.06.2008 № 1092/5/54, надсилають такий запит до центральних органів запитуваної держави напряму.

Компанія "Міжнародне вручення процесуальних документів" $є$ єдиною приватною компанією, що здійснює вручення процесуальних документів, уповноваженою діяти від імені центрального органу США відповідно до ст. 2-6 вищезазначеної конвенції, отримувати запити про вручення від інших договірних держав, здійснювати вручення документів, заповнювати формуляри.

Згідно зі ст. 2, 3, 4 конвенції кожна договірна держава призначає центральний орган, обов'язком якого $€$ отримання прохань про вручення документів, що виходять від інших договірних держав, і здійснення процесуальних дій відповідно до положень ст. 3-6. Орган влади чи судовий працівник, компетентний відповідно до права запитуючої держави, направляють центральному органу запитуваної держави прохання згідно із формуляром, що додається до цієї конвенції, без потреби легалізації або виконання інших аналогічних формальностей. До прохання додається документ, що підлягає врученню, або його копія. Прохання і документ надають у двох примірниках. Якщо документ має бути вручений відповідно до частини першої цієї статті, то центральний орган може вимагати, щоб документ був складений або перекладений офіційною мовою або однією з офіційних мов запитуваної держави.

У ст. 12 конвенції зазначено, що вручення судових документів, отриманих від договірної держави, не потребує оплати або відшкодування зборів чи витрат у зв'язку із врученням, здійсненим запитуваною державою. Запитуючий орган сплачує або відшкодовує витрати, що виникли у зв'язку з: а) виконанням роботи судовим працівником або особою, компетентною відповідно до закону запитуваної держави, б) використанням особливого способу вручення.

У своєму листі Міністерство юстиції України від 04.10.2004 за № 25а-84-04 повідомляло про те, що згідно 3 повідомленням від 1 жовтня 2002 р. [12], розміщеним на офріційному сайті Гаазької конференції, Департамент юстиції США вирішив передати виконання своїх повноважень відповідно до ст. 2 Гаазької конвенції 1965 р., наголосивши, що зазначена процедура не веде до формального призначення нового центрального органу, а радше до відокремлення діяльності, що здійснюється центральним органом, яким формально залишається Департамент юстиції. У повідомленні від 15 квітня 2003 р. Департамент юстиції США проінформував Пос- тійне бюро Гаазької конфреренції про закінчення процедури передачі зазначених повноважень й укладання договору з компанією Міжнародне вручення процесуальних документів - Сіетл, штат Вашингтон, США (Process Forwarding International of Seattle). Оплата має здійснюватися у валюті США, умови оплати (передоплата), вартість вручення становить: у 2003 р. - 89 дол, у 2004 - 91, у 2005 - 93, у 2006-2007 рр. - 95 дол. Способи оплати: VISA/MasterCard і більшість міжнародних кредитних карток, банківські перекази, міжнародні грошові накази, видані урядом чеки. Усі запити про вручення, що не супроводжені належною оплатою способом, зазначеним вище, повертаються без вручення.

За даними офріційного сайту Process Forwarding International of Seattle (далі - Компанія) [13] між Департаментом юстиції США та Компанією 30 січня 2015 р. набув чинності новий контракт, яким продовжено на п'ять років термін виконання Компанією повноважень щодо вручення судових документів. Натепер вартість вручення становить 95 дол США. Оплату за проведення дій із вручення документів позивачу необхідно здійснити на рахунок компанії "Міжнародне вручення процесуальних документів".

Отже, судові витрати, пов'язані з виконанням судових доручень, звернених до компетентних органів іноземних держав, можна поділити на такі види:

- витрати, пов'язані із засвідченням перекладу позовної заяви та доданих документів офіційною мовою запитуваної держави;

- витрати, пов'язані із проведенням дій із вручення документів.

Порядок відшкодування судових витрат. Разом із першою заявою по суті спору кожна сторона подає до суду попередній (орієнтовний) розрахунок суми судових витрат, які вона понесла і які очікує понести у зв'язку із розглядом справи. У разі неподання стороною попереднього розрахунку суми судових витрат суд може відмовити їй у відшкодуванні відповідних судових витрат, за винятком суми сплаченого нею судового збору. Попередній розрахунок розміру судових витрат не обмежує сторону в доведенні іншої фрактичної суми судових витрат, які підлягають розподілу між сторонами за результатами розгляду справи. Суд може попередньо визначити суму судових витрат (крім витрат на професійну правничу допомогу), пов'язаних із розглядом справи або певною процесуальною дією. Така попередньо визначена судом сума не обмежує суд при остаточному визначенні суми судових витрат, що підлягають розподілу між сторонами за результатами розгляду справи (ст. 134 ЦПК України).

Відповідно до ч. 2 ст. 141 ЦПк України інші судові витрати, пов'язані з розглядом справи, покладаються:

- у разі задоволення позову - на відповідача;

- у разі відмови в позові - на позивача;

- за умови часткового задоволення позову - на обидві сторони пропорційно розміру задоволених позовних вимог.

Отже, вважаємо за доцільне віднести витрати, пов'язані із виконанням судових доручень, звернених до компетентних органів іноземних держав, до витрат, пов'язаних із розглядом справи, а саме до витрат, що пов'язані з учиненням інших процесуальних дій, необхідних для розгляду справи або підготовки до ії розгляду. Це забезпечить право зацікавленої сторони в майбутньому на відшкодування таких витрат. 
Висновки. За результатами проведеного дослідження ми пропонуємо такі висновки. Судові витрати, пов'язані із виконанням судових доручень, звернених до компетентних органів іноземних держав, варто поділити на: а) витрати, пов'язані із засвідченням перекладу позовної заяви та доданих документів офіційною мовою запитуваної держави; б) витрати, пов'язані зі здійсненням дій із вручення документів. Доцільно віднести витрати, пов'язані з виконанням судових доручень, звернених до компетентних органів іноземних держав, до витрат, що пов'язані з учиненням інших процесуальних дій, необхідних для розгляду справи або підготовки до її розгляду, оскільки так забезпечено гарантії зацікавленої сторони реалізувати своє право на відшкодування таких витрат.

Список використаних джерел:

1. Цивільний процесуальний кодекс України від 18 березня $2004 \mathrm{p}$. в редакції Закону України від 13 лютого 2020 р. зі змінами та доповненнями. URL: https://zakon.rada.gov.ua/laws/show/1618-15\#n7328 (дата звернення: 29.02.2020)

2. Конвенція про захист прав людини і основоположних свобод від 01 січня 1990 р. в редакції Закону України від 02 жовтня 2013 р. зі змінами та доповненнями. URL: https://zakon.rada.gov.ua/laws/show/ 995_004 (дата звернення: 29.02.2020).

3. Рекомендація щодо заходів, які полегшують доступ до правосуддя № R (81)7, прийнята Комітетом міністрів Ради Європи 14 травня 1981 p. URL: https://zakon.rada.gov.ua/laws/show/994_133 (дата звернення: 29.02.2020)

4. Справа "Креуз проти Польщі" (CASE OF KREUZ v. POLAND) від 19 червня 2001 p. URL: https://zakon.rada.gov.ua/laws/show/980_030 (дата звернення: 29.02.2020).

5. Ухвала Нікопольського міськрайонного суду Дніпропетровської обл. № 182/7393/19 від 28 жовтня 2019 p. URL: http://reyestr.court.gov.ua/ Review/83982856 (дата звернення: 29.02.2020)

6. Ухвала Токмацького районного суду Запорізької обл. № 328/131/19 від 18 січня 2019 p. URL: http://reyestr.court.gov.ua/ Review/79259387 (дата звернення: 29.02.2020).

7. Ухвала Приморського районного суду м. Одеси № 522/18132/19 від 08 липня 2019 p. URL: http://reyestr.court.gov.ua/Review/82889913 (дата звернення: 29.02.2020).

8. Ухвала Дніпропетровського районного суду Дніпропетровської обл. № 175/3613/17 від 29 січня 2019 р. URL: http://reyestr.court.gov.ua/ Review/79519848 (дата звернення: 29.02.2020).

9. Ухвала Індустріального районного суду м. Дніпропетровська № 202/4354/19 від 01 липня 2019 p. URL: http://reyestr.court.gov.ua/ Review/82755487 (дата звернення: 29.02.2020).

10. Ухвала Новоайдарського районного суду Луганської обл. № 419/2850/17 від 26 березня 2018 р. URL: http://reyestr.court.gov.ua/ Review/72947154 (дата звернення: 29.02.2020)

11. Ухвала Нікопольського міськрайонного суду Дніпропетровської обл. № 182/5601/19 від 03 вересня 2019 p. URL: http://reyestr.court.gov.ua/Review/83982856 (дата звернення: 29.02.2020).

12. Лист Міністерство юстиції України від 04 жовтня 2004 р. за № 25a-84-04 щодо надання роз'яснень. URL: https://zakon.rada.gov.ua/ laws/show/v4-04323-04 (дата звернення: 29.02.2020).

T. Korotenko, PhD Student

Kyiv University of Law, NAS of Ukraine, Kyiv, Ukraine
13. United States of America Central Authority under the Hague Convention of 15 November 1965 on the Service Abroad of Judicial and Extrajudicial Documents in Civil or Commercial Matters. URL: https://www.hcch.net/es/news-archive/details/?varevent=5 (дата звернення: 29.02.2020)

References:

1. Cyvil'nyj procesual'nyj kodeks Ukrai'ny 18 bereznia 2004 r. v redaktsii Zakonu Ukrainy vid 13 liutoho 2020 roku zi zminamy ta dopovnenniamy: URL: https://zakon.rada.gov.ua/laws/show/1618-15\#n7328 (in Ukrainian).

2. Konventsiia pro zakhyst prav liudyny i osnovopolozhnykh svobod vid 01 sichnia 1990 roku v redaktsii Zakonu Ukrainy vid 02 zhovtnia 2013 r. zi zminamy ta dopovnenniamy. URL: https://zakon.rada.gov.ua/laws/ show/995_004 (in Ukrainian).

3. Rekomendatsiia shchodo zakhodiv, yaki polehshuiut dostup do pravosuddia № R (81)7, pryiniata Komitetom ministriv Rady Yevropy 14 travnia 1981 roku. URL: https://zakon.rada.gov.ua/laws/show/994_133 (in Russian).

4. Sprava "Kreuz proty Polshchi" (CASE OF KREUZ v. POLAND) vid 19 chervnia 2001 roku. URL: https://zakon.rada.gov.ua/laws/show/980_030 (in Ukrainian)

5. Ukhvala Nikopolskoho miskraionnoho sudu Dnipropetrovskoi oblast № 182/7393/19 vid 28 zhovtnia 2019 roku. URL: http://reyestr.court.gov.ua/ Review/83982856 (in Ukrainian).

6. Ukhvala Tokmatskoho raionnoho sudu Zaporizkoi oblasti №328/131/19 vid 18 sichnia 2019 roku. URL: http://reyestr.court.gov.ua/ Review/79259387 (in Ukrainian).

7. Ukhvala Prymorskoho raionnoho sudu m. Odesy № 522/18132/19 vid 08 lypnia 2019 roku. URL: http://reyestr.court.gov.ua/Review/82889913 (in Ukrainian).

8. Ukhvala Dnipropetrovskoho raionnoho sudu Dnipropetrovskoi oblasti №175/3613/17 vid 29 sichnia 2019 roku. URL: http://reyestr.court.gov.ua/ Review/79519848 (in Ukrainian).

9. Ukhvala Industrialnoho raionnoho sudu $\mathrm{m}$. Dnipropetrovska № 202/4354/19 vid 01 lypnia 2019 roku. URL: http://reyestr.court.gov.ua/ Review/82755487 (in Ukrainian)

10. Ukhvala Novoaidarskoho raionnoho sudu Luhanskoi oblasti №419/2850/17 vid 26 bereznia 2018 roku. URL: http://reyestr.court.gov.ua/ Review/72947154 (in Ukrainian)

11. Ukhvala Nikopolskoho miskraionnoho sudu Dnipropetrovskoi oblasti № 182/5601/19 vid 03 veresnia 2019 roku. URL: http://reyestr.court.gov.ua/ Review/83982856 (in Ukrainian).

12. Lyst Ministerstvo Yustytsii Ukrainy vid 04 zhovtnia 2004 roku za N 25a-84-04 shchodo nadannia roziasnen. URL: https://zakon.rada.gov.ua/ laws/show/v4-04323-04 (in Ukrainian).

13. United States of America Central Authority under the Hague Convention of 15 November 1965 on the Service Abroad of Judicial and Extrajudicial Documents in Civil or Commercial Matters. URL: https://www.hcch.net/es/news-archive/details/?varevent=5 (in English).

Received: $01 / 03 / 2020$

1st Revision: $25 / 03 / 2020$

Accepted: $15 / 04 / 2020$

\section{COURT FEES RELATED TO THE COURT ORDER FOR THE COMPETENT AUTHORITIES OF FOREIGN STATES}

The article explores the court fees related to the execution of court orders, which are addressed to the competent authorities of foreign states in civil cases with a foreign element. The Civil Procedure Code of Ukraine does not state that the costs associated with the execution of court orders, addressed to the competent authorities of foreign states, are court fees. Therefore, the questions on which of the above fees can be attributed to the courts fees and the procedure for their reimbursement are raised. The importance of clarifying these issues requires the application of the uniform approaches to such cases consideration in Ukrainian courts. It is determined as the main purpose of this article. The case-law shows that in most cases where a court needs to apply to a competent authority of a foreign state, the person concerned must pay for the certified translation of the statement of claim and the attached documents into the official language of the requested state and pay for service of documents. In our conclusions, we propose to divide the court fees associated with the execution of court orders addressed to the competent authorities of foreign states, depending on the procedural actions that are being carried out, and to include the fees associated with the execution of court orders addressed to the competent authorities of foreign states, to the fees associated with the case, namely to the fees associated with other procedural acts necessary to the case consideration or to prepare for its consideration, which will ensure the right of the interested party to reimburse such fees in future.

Keywords: court fees, litigation costs, a foreign element, civil litigation. 